\title{
Study on Origin of English and Chinese Proverb*
}

\author{
Rongmei Yu \\ NanChang Normal University, China
}

\begin{abstract}
Proverbs are the summary of class struggle, working practice and life experience of human beings. Proverbs represent the unique characteristics and cultural features of a nation. People of various cultural backgrounds communicate with each other. Cross-cultural communication has been the focus of the present era. Only through communication can we learn from each other and come to know each other better. Only through communication can we give full play to human wisdom and enjoy the common fruits of civilization. The achievements brought about by cultural communication can never be over-estimated. Therefore, in order to gain a better cross-cultural communication with English speaking countries, it's not only important but also necessary to understand the English and Chinese proverbs and their origins from a cultural perspective. This thesis analyzes and compares the cultural differences between English and Chinese proverbs from four aspects---Human experiences, Literary works, Religions and Social discrimination.
\end{abstract}

Index Terms - English and Chinese proverbs, cross-cultural communication, origins

\section{INTRODUCTION}

A distinctive feature of human beings is that they possess linguistic power, which magically links people sharing the same or different cultural backgrounds together. Language, known as the cultural carrier, serves as a bridge through which cross-cultural communication has been made possible. Being the cream of language, proverbs play an indispensable role in cross-cultural communication.

With the aid of the Hi-Tech of the 20th century, the planet on which the human beings are living is on its fast track to become a global village. No country in the world can afford to be well developed itself economically and culturally without keeping its door widely open to the outside world. Cultural exchange, an indispensable part of social advancement, is no exception. It is a trend in the development of human society. The history has again and again proved that culture needs exchanging and peoples need to communicate. The achievements brought about by cultural exchange can never be over-estimated. Since proverbs are a general summary of human experiences, and no aspect of life remains yet to be untouched by proverbs, it is no exaggeration to say proverb study can play a major role in introducing various human experiences to people of different cultures. It can familiarize people of one country with the cultural heritage of the other, thus achieve the goal of cultural exchange. In a sense, proverbs serve as a mirror of the historical and cultural conceptions of a social community, reflecting the panoramic picture of linguistic and cultural traits of that community in a most concentrated and profound way. Proverb study is, in fact, a question of apt treatment of different cultural traits indicated by proverbs.

As far as cross-cultural communication is concerned, proverb study should be approached in a way that always takes the culture background of the proverb into consideration. To study the proverbs, one also should do the careful work of origins of the proverbs; achieving this, it will be easier to understand the proverbs.

Definitions of Proverb and Culture

Proverbs are the record of class struggle, working practice and life experience of human beings. They usually refer to some fixed meaningful sentences, which, bearing national and cultural features, are found, selected, refined and accumulated in the long course of language and social development. Just as clothes are to women, so proverbs are to language. Without clothes, women's charms would be reduced; similarly, without proverbs, a language would be barren and insipid, void of vitality, vividness and expressiveness. Although there are discussions and publications on proverbs, close study of this subject is far from satisfactory. In order to get an overview of proverb, a general knowledge of proverbs is necessary and instrumental.

According to the Random House Webster's College Dictionary, a proverb is "A short popular saying, usually of unknown and ancient origin, that expresses effectively some commonplace truth or useful thought" (p. 1456). What strike the author most in this definition are "short saying", "ancient origin" and "commonplace truth and thought". A similar definition is offered by the Collins English Dictionary, which goes like this: "A proverb is a short, memorable, and often highly condensed saying embodied, esp. with bold imagery, some commonplace fact of experience" (p.1176). In addition to its shared features with the above-mentioned definition, one more striking point from this one is "bold imagery" which, combined with the overlapped features, produces a more comprehensive impression on readers. Since in this dissertation a general study of both English and Chinese proverbs is to be undertaken, a definition from an authoritative Chinese dictionary will more or less strike a balanced impression on the public readers. Cihai(《辞

\footnotetext{
${ }^{*}$ This paper is funded by 11531 project of Nanchang Normal University
} 
海》)gives a definition like this“熟语的一种。流传于民间的简练通俗而富有意义的语句，大多反映人民生活和斗 争的经验”). Based on the definitions offered by different sources, a conclusion can be safely drawn that a proverb is such a saying, popularly known and repeated, usually expressed simply and concretely, though often metaphorically, a truth based on common sense or practical human experiences.

Proverbs, a unique part of a language, represent the unique characteristics and cultural features of a nation. In content, proverbs are closely connected with history, everyday life and living conditions of a nation. In spite of the fact that both Chinese proverbs and English proverbs embedded respectively in their unique cultures share much in common, they, after all, belong to two different language systems of the different language families, so the disparities between them outweigh their similarities.

\section{ORIGINS OF ENGLISH AND ChINESE PROVERBS}

As already noted, the most outstanding feature of proverbs is the distinctive cultural traits condensed in their pithy forms. Proverbs are all of distinctive nature and they are culturally specific. The larger a cultural gap there exists between two languages, the more difficult interpretation proverb will be.

Proverbs are the fruits of the development of language and culture, and manifest "the way of life" of the two nations in various respects. Being linguistically specific, they cannot be appreciated without taking their language settings into consideration. Being culturally specific, they can hardly be rendered without their cultural deposits recognized. Therefore, the combination of language elements and highly diverse cultures contributes to the difficulty of proverb understanding, with the difficulty brought about by cultural differences outweighing the difficulty caused by language elements.

Because of all the cultural diversities indicated by proverbs, people should be able, for the most part, to adjust their cognitive angle as they move from one proverb to another, for the fact that proverbs belong to a particular language indicates a particular culture. What the cultural traits expressed by proverbs of one language may not be represented accurately by those of another due to the cultural gap in between. Additionally, in order to convey the same concept or idea, proverbs of different languages may resort to different cultural images and means; expressions. All these have revealed the necessity that in case of proverb understanding we must take cultural features into serious consideration.

\section{A. Proverbs Originate from Human Experiences}

Human experiences hold an enormously broad impact on the coinage of proverbs. People have drawn, by various means, ever so many elements from their daily practice to invent numerous proverbial expressions. Just as a famous 17th century British priest named Robert South (1634-1716) wrote in his mufti-column book entitled Sermons: what a proverb, but the experience and observation of several ages, gathered and summed up in one expression? It goes without saying that most proverbs come from the colloquial speech of the common people, for through their practical work people have created a great number of proverbs, just as sailors in Britain have invented many lively sea proverbs, laborers in the fields have created expressions concerning farm work and workers from occupations of all kinds have given birth to numerous proverbs concerning their daily practice. These proverbs are terse, colloquial, vivid and charged with life; therefore, they acquire a wide application to analogous situations in everyday life, and finally come to be universally understood.

1. English Proverbs from human experiences

(1) Make hay while the sun shines.

The first reading strikes the readers that this English proverb tells the farmers to take the advantage of sunshine to dry some hay in case of rainfall. However, it carries more profound meaning than its literal rendition. Apart from its literal meaning, this proverb produced by English farmers indicates that one should make full use of something while it is still available, for chances lost will be lost forever. This being the case, a literal version and an adding of its implication will produce a vivid and correct impression “晒草趁天好, 行事见良机, ” on the Chinese readers.

(2) You may take a horse to the river, but you cannot make him drink.

Apart from proverbs concerning nautical activities, hunters also give birth to many proverbial expressions according to their hunting experiences. On the surface level, each proverb is telling people some self-evident fact, but the truth is, more often than not, hidden behind.

(3) Can the leopard change his spots?

It is a proverb adopting the self-questioned and self-answered rhetorical device with no intention to seek for an answer. To change the leopard of his spots is tantamount to changing people's nature, which is unlikely to be achieved. The author suggests a humble version“豹难改花斑, 人难改本性, with the former part rendered by literal approach while the latter added as its implied implication.

(4) An old fox is not easily snared.

What a pleasant coincidence it is! Both English people and Chinese people hold the same view that fox is sly. And "as sly as fox" and“狡猾得像狐狸一般”carry the same meaning with the same images in two different cultures. Therefore, a literal version“老狐狸难得陷罗网”is sufficient to touch the feeling of the Chinese people that experienced, shrewd, and even cunning people are not easily to be deceived. 
Compared with hunters and fishermen, housewives in Britain never fell behind the others in producing vivid colorful proverbs relevant to their daily routine. For example:

(5) A watched pot never boils.

This proverb tells us an obvious truth that over care and anxiety does not help things. So“老是看壸水不开, provided by the author can be reckoned as a faithful version.

(6) Omelets are not made without breaking of eggs.

It is said by way of warning to one who is trying to get something for nothing to accomplish some denied object without being willing to take the necessary trouble or make the necessary sacrifice.“鸡蛋不打破，难以做蛋卷”is considered to be both to the meaning and to the style of the original proverb.

No matter how much we have devoted to the discussion of human experiences, they can by no means be complete without taking the summarization of British people's long years of weather observation into consideration because weather plays a decisive role in their agricultural and husbandry output. Accordingly, proverbs of this kind find their expressions in their respective fields. For instance:

(7) Under water, famine; under snow, bread.

水没庄稼, 来岁饥荒:雪覆农田, 面包在望。

(8) A rainbow in the morning is the shepherd's warning; a rainbow at night is the shepherd's delight.

清晨彩虹暮必雨, 羊倌警觉在心里; 晚霞贯空翌日晴, 羊倌心会有好心情。

Examples (7) and (8) reveal respectively the significant role these proverbs play in the instruction of farmers in their endless struggle against nature.

2. Chinese Proverbs from Human Experiences

China is a big country mainly of agricultural nature, especially in the past, although significant development has taken place in industry in modern times. Related to agricultural activities or experiences are an enormous number of proverbs which are probably incomparable. So, in all above-listed aspects of the English society, Chinese people are never willing to lag behind in producing their proverbs. These proverbs are used not only literally to suggest a summary of learned experience, but also metaphorically to connote a truth in a concise and witty way. See some examples below:

(9) 要知朝中事, 乡间问老农。

Ask the common folk if you want to know how the country is faring.

This is not a very catchy proverb, but it contains a bit of universal folk wisdom, experiences are derived from daily practices.

(10) 种瓜得瓜, 种豆得豆。

Plant melons and you get melons, sow beans and you get beans.

A literal version of this proverb convinces English readers of the Chinese farmers' daily practice and their simple summarization of the essential properties of objects and the objective law governing their development. A more glance of this proverb call into English people's mind a similar proverb in their own culture "As you sow, so will you reap." if we do things subjectively and violate these laws, we will run into difficulties and be foiled everywhere. Both Chinese and English proverbs reveal an objective law, but the English one expresses a more general idea, whereas the Chinese equivalent is more specific.

(11) 瓜田不纳履, 李下不整冠。

Neither adjust your shoe in a melon patch; nor your hat under a plum tree to avoid arousing suspicion.

The pure literal understanding of this proverb fails to encourage English-speaking readers to dig out the implied meaning of the Chinese proverb which actually gives advice to people on how to behave .themselves in certain circumstances or surroundings, since to adjust one's shoe in melon patch may produce an false impression of attempting to steal melons and to adjust one's hat under a plum tree may arouse other people's suspicion of one's plum picking attempt. So the explanatory phrase "to avoid arousing suspicion" is very much necessary to reveal the intention of so doing.

(12) 留得青山在，不怕没柴烧。

As long as the green mountains are here, one need not worry about the firewood.

This proverb at least reveals to English readers that ancient Chinese people's main source of fuel was the firewood obtained from the mountains before coal was discovered. At the same time, it reveals people's attitude towards life: where there is life, there is hope. Literal understanding should be adopted to convey this cultural element to the target language readers. But this proverb is often quoted to describe that as long as human resource is kept, we are confident of achieving success.

(13) 巧妇难为无米之炊。

Even the cleverest wife can't cook rice without rice grains.

It lays emphasis on the fact that materials are the source of all things on earth, and man can not live without them. So the literal interpretation can strike a vivid impression on an English readers that even the most competent person cannot accomplish his intention when lacking the necessary materials or conditions.

(14) 不当家，不知柴米贵。

The head of the house knows the cost of fuel and rice. 
The proverb, on the one hand, indicates that he who takes charge knows the responsibility, on the other hand, reveals to English readers the distinctive cultural features of the ancient Chinese families, that is, firewood and rice were their necessities.

Those above-mentioned two examples are all housewives' pithy summaries of their experiences marked with distinctive Chinese cultural features. Like English hunters, Chinese ones also take part in the creation of numerous Chinese proverbs in this regard.

(15) 不入虎穴，焉得虎子?

How can you catch tiger cubs without entering the tiger's lair?

This proverb tells us that one cannot expect to achieve success without experiencing difficulties and risks; only those who are bold in exploring and not afraid of hardships and dangers can achieve success. It employs the rhetorical question to make a clear fact even clearer. So the literal translation is highly recommendable to keep the meaning and style in one sentence with no need to offer an answer.

(16) 狼披羊皮还是狼。

A wolf remains a wolf even in sheep's clothing.

It conveys a warning that people must not easily believe what a person propagandizes if he is evil in nature even though he may employ the high-flown language. A literal rendition of this proverb will not cause misunderstanding among English readers, for English-speaking people have a similar idiom "a wolf in sheep's clothing" in their language. Just as what has been shown above, weather exercises great influence on farmers' agricultural activities and their practical life. Here are several Chinese proverbs that reflect Chinese farmers' patient observation of the law governing the change of the weather.

(17) 早霞不出门, 晚霞行千里。

Don't leave the house in the morning glow; but go for a long journey in the evening glow.

This proverb having a striking resemblance with the English proverb shown above "a red sky at night is the shepherd's delight; a red sky in the morning is the shepherd's warning" indicates the experiences shared by both Chinese and English peoples. Therefore, this pleasant coincidence makes the English version of this Chinese proverb quite easy for English readers to understand.

(18) 蚂蚁搬家蛇过道，水缸出汗蛤蟆叫，燕子低飞山戴帽，不久将有大雨到。

A heavy rain is soon coming when the ants are moving and the snakes across the path slipping, the water jars perspiring and the toads croaking, the swallows hovering and the mountains a white cap wearing.

There is no doubt that this jingle witty proverb could by no means obtain the present form without working people's meticulous observation. Only through literal understanding, can Chinese farmers' painstaking efforts in weather observation be vividly presented before English readers.

Human experiences are inexhaustible resources that provide abundant language materials for the constitution of proverbs. People from all walks of life sum up their daily practice in forms of proverbs, and a comparative study of Chinese and English proverbs reveals how people from both nations fashion their languages into the condensed present forms from daily activities they are engaged in.

\section{B. Proverbs Originate from Literary Works}

Literature proves to be one of the most important sources of proverbs in both English and Chinese. The existence of oceans of vivid and expressive proverbs would be unimaginable without so many excellent literary works in both languages.

1. English Proverbs from Literary Works

The merit for the abundance of the English proverbs should, to a large extent, go to William Shakespeare's plays from which spring up a great number of proverbs involving events and characters. These proverbs and the rich connotations reflected by them have become a part of their life so that they quote them in their daily speech and writing often even without definite consciousness of their origin.

As a matter of fact, proverbs from Shakespeare's works have enriched the English language so lavishly that nobody dares to predict what the time-honored English language would be like without that literary giant. The following examples are all proverbial expressions that found their way into Shakespeare's works.

(19) The course of true love never did run smooth.

爱情路上无坦途。

The literal rendition of this proverb echoes the same feeling in the Chinese people no love can be free from setbacks and torments. The true love does surely experience the ups and downs, twists and turns that in turn will strengthen the bond of love between people. Proverbs from Shakespeare's works are bountiful; a mere mention of a few is enough to impress Chinese readers with the richness of the treasure the English literator Shakespeare left behind him.

(20) The wish is father to the thought. .

愿望是思想之父。

(21) Discretion is the better part of valor. 谨慎为勇敢之本。

(22) When the cat is away; the mice will play. 
猫儿不在家，老鼠闹翻天。

(23) Appetite grows by eating.

胃口越吃越开。

Of course, there are also numerous proverbs from English poets and other writers in the English language and those proverbs have passed into the thought of common people who can pick up any of them and employ it in their conversation without consciously knowing its origin. The following proverbs show how the wit and wisdom of English poets and other writers have found their expressions among the common people.

(24) A little learning is a dangerous thing. (Pope, Essay in Criticism) 一知半解是件危险的事情。

(25) God helps those who help themselves. (Franklin, Zichard's Almanac) 天助自助之人。

(26) Reading makes a full man, conference a ready man, writing an exact man. 读书使人充实, 讨论使人机智, 笔记使人准确。

The above examples are so popular that they have, as Dr. Bradley Henry Bradley, 1845-1925), an English lexicographer, puts it, "entered into tree texture of the diction of literature and daily conversation" and may now "fairly be regarded as proverbs of the English language."

2. Chinese Proverbs from Literary Works

The same is true of the Chinese people who also enjoy a large treasure of literature with numerous proverbs in store. Even though to exhaust the source of each proverb will prove to be hard, still The Romance of the Three Kingdoms is sure to be one of the most important sources. As a Chinese classical novel, it plays an equally significant role in Chinese literary history as Shakespeare's plays do in English literary history. The novel boasts a large number of breathtaking events and heroic characters. They are so familiar to and so popular among the Chinese people that they are cited commonly in daily conversation. What is more, with their allusions there, those proverbs are frequently quoted not only to convey their denotative meaning but more importantly, to suggest some connotative meaning metaphorically.

(27) 三个臭皮匠, 顶个诸葛亮。

Three cobblers with their wits combined equal Zhuge Liang the mastermind the wisdom of the masses exceeds that of the wisest individual.

Zhuge Liang, a Chinese historic figure noted for his marvelous military schemes and unrivalled martial strategy and tactics, has acquired the special meaning of being wise in Chinese culture, as "Solomon" as well as "Homer" does in English culture. This may be very hard to be appreciated by average English readers if explanatory phrase is not offered.

(28) 万事俱备, 只欠东风。

Everything is ready except the east wind that is crucial.

This proverb, derived from a story concerning the kingdoms of Wei, Shu and $\mathrm{Wu}$, means that everything is ready except what is crucial. The east wind in this story played a decisive role in determining which side would take the upper hand of the other.

(29) 司马昭之心, 路人皆知。

Sima Zhao's ill intention is known to all.

The literal understanding of this Chinese proverb that keeps the image of Sima Zhao serves the purpose of introducing the Chinese culture to the English-speaking people, if cross-cultural communication is intended. But the historic figure Sima Zhao should be explained as far as his background is concerned; otherwise the inadequacy will readily lead to confusion among target readers. Sima Zhao was a Prime Minister of Wei (220-265) who nursed a secret ambition to usurp the throne. The emperor once remarked, "Sima Zhao's intention is obvious to every man in the street."

Both Chinese and English literally works contains a great deal of significant and useful proverbs. Different works provide a source from the different proverbs which reflect the different culture background.

\section{Proverbs Originate from Religions}

Religion is another important source that has given rise to numerous proverbs in both Chinese and English. It is known that religion came into being at the time when society as a whole remained backward and people could hardly explain satisfactorily many seemingly unnatural events when actually confronted with various natural phenomena. Gradually, mysterious religion came to their rescue. Religion once had and still has an immense influence on people's behavior, and mind, thought, etc. Naturally, these religions found their expressions in languages, especially in proverbs, the cream of language, which mirror different events taking place at various stages of human development. Owing to their different religious beliefs, English and Chinese people use different figures in their own proverbs with religious allusions. "God", "heaven", "Devil", "Hell", "Church", etc. are often used in Christianity, whereas“佛”(Buddha),“庙”(temple),“和尚”(monk), etc. in Buddhism.

1. English Proverbs from Religion

Christianity, the dominant religion in the West, has played a key role in people's life, the significance of which can never be overstated. As a result, many English proverbs came from the Bible, textbook of Christianity. For instance: 
(30) A tree is known by its fruit (Matthew).

观果实可知树, 观其行可知人。

According to Matthew 12, a chapter of the Bible, Jesus says that to make a tree good and its fruit will be good, or to make a tree bad and its fruit will be bad, for a tree is recognized by its fruit. The implied meaning of this proverb is that a person can be known by his behavior. So, it is quite essential to bring out the implied meaning in its Chinese version.

(31) Out of the overflow of the heart the mouth speaks (Matthew).

口里所言的是心里所有的。

As Jesus states, the good man brings good things out of the good stored in him, and the evil man brings evil things out of the evil stored in him. Therefore, it is natural that what one speaks is what one thinks.

(32) The spirit is willing, but the flesh is weak (Matthew). 心有余而力不足。

Man has numerous good intentions, but the limitation of his ability, wealth, and wisdom makes his intentions unfulfilled.

(33) Men leap over where the hedge is lowest (Genesis). 篱矮有人跨, 心软有人欺。

A self-evident phenomenon is employed to convey the fact that man of little or none resistance against the bullying force will surely be ridden roughshod over.

(34) Judge not, that ye be not judged (Matthew). 不要对人非议, 以免自己有非议。

This proverb warns people that to judge others, you will be judged by others in the same way, and in the measure you use, you will be measured yourself.

(35) Sufficient unto the day is the evil thereof (Matthew).

当天苦恼已足够, 莫为明日枉发愁。

It implies that anticipating future anxieties is unnecessary, for people have sufficient problems to solve today. Advanced worry about tomorrow's events will do no good but increase the burden of today; therefore people are supposed not to confront and deal with tomorrow's problems until tomorrow comes.

Proverbs from the Bible are so rich that a mere mention of a few is enough to manifest how lavishly they had enriched the English culture.

2. Chinese Proverbs from Religion

Unlike Christianity, there seems to be no particular religion holding a controlling position in China so far.

Buddhism and Taoism used to be comparatively popular among some of the Chinese people in the past. Therefore, monk, temple, Buddha, etc. are borrowed to coin Chinese proverbs. For example:

(36) 道高一尺, 魔高一丈。

The law is strong, but the outlaws are ten times stronger.

The metaphorical meaning is always surpassed by the newcomer that goodness, which is easy to lose when the evil things of this proverb is the present winner.

(37) 放下屠刀, 立地成佛。

The butcher, who lays down his knife, at once becomes a Buddha--a saintly person.

This proverb tells us that even an evildoer can become a good person as long as he sincerely repents and earnestly reforms himself.

(38) 平时不烧香, 临时抱佛脚。

Never burning incense when all is well, but clasping Buddha's feet in an emergency.

This proverb warns us to take precautions against all emergencies, and not wait for disasters to strike. If the necessary preparation is not adequate, any rash remedy will be too late.

(39) 一人得道, 鸡犬升天。

When a man is in power, all his followers like chickens and dogs are in favor.

This proverb is derived from a fairy tale that goes like this:a man who had attained the secret of immortality was about to ascend to Heaven. He fed his dogs and chickens with some of the elixir he had used. So the dogs and chickens went up to Heaven together with him. It is used metaphorically to mean that when a man rises in status, all his friends and relations - - even the most humble will benefit.

(40) 一个和尚挑水吃, 两个和尚抬水吃, 三个和尚没水吃。

Owing to its unique way of expression and specific cultural manifestation, this Chinese saying presents a challenge for the translators to render into English. Versions of several kinds have been suggested with one preferable by the author of this thesis going like this:

A lone monk brings his own bucket of water to drink, two monks carry their bucket of water jointly, but when three monks are together, there is no water at all more hands, less work done.

The target readers may familiarize themselves with the Chinese culture by reading this English version, but at the same time, they may be confused about the way they obtain the water. Because temples in China used to be built in the mountains, far away from the crowd, monks can obtain drinking water only from the rivers or the wells at the foot of 
the mountains by using bucket to fetch.

From the above-mentioned proverbs both from English ;and Chinese, one can see effortlessly that religion is an essential component of culture, and the different religious beliefs people hold make one culture so distinctive and colorful from the other. Proverbs are the mirror of the development and influence of religion, mostly through literal understanding can accordingly serve the cross-cultural communication fine.

\section{Proverbs Originate from Social Discrimination.}

Although society as a whole has advanced significantly, it still leaves much room to be desired in many aspects. Before everyone on the earth enjoys the true equality, we still need to go a long way to fulfill that aim. Social discrimination as it was has taken its root in many aspects. As a result, no one can claim that everyone in his country enjoys equal opportunity, respect and treatment, for it still needs some time for the planet to become an ideal global village in which every global citizen will not be judged by the color, but by one's character; not by sex, but by one's work; not by the position one holds, but by the contribution he makes to the society. So, it goes without saying that progress of development of every society is stamped with the brand of discrimination of various kinds. As an indicator of the culture traits, proverbs reflect these social events in a crystal way.

One is sex discrimination. Even though women's position in their families and society has been enhanced to a great height, it is still far from being satisfactory. Sex discrimination is deep-rooted in China as well as in foreign countries. As a result, women fall inevitably victims to this prejudice. Examples speak louder than words.

1. English Proverbs from Social Discrimination

(41) Women have no souls.

$$
\text { 女人没有灵魂。 }
$$

(42) When an ass climbs a ladder, we may find wisdom in women. 驴子能上梯, 女人才会有智慧。

(43) Tell a woman she is fair and she will soon turn fool. 跟女人讲她漂亮, 很快她就会晕头转向。

The above examples show that ignorance goes hand in hand with women. We hold it a self-evident truth that women are as capable, if not more than, as men in many aspects. Distorted pictures of women were caused by society in which men and women were treated differently to a remarkable extent.

(44) Women are saints in church, angles in the street, and devils at home. 女人在教堂里是圣人, 在大街上是天使, 在家里是魔鬼。

(45) A woman's tongue is the last thing about her that dies. 女人身上最后死去的部分是舌头。

We know that no evidence so far has proved that women are born with the instinct to gossip or to be affected. From versions of these proverbs, Chinese readers can acquaint themselves with the sex injustice in English-speaking countries.

Apart from sex discrimination, other prejudice exists as well, which has caught the attention of many socio-linguists in recent years.

(46) To a red man read thy red, with a brown man break thy bread, at a pale man draw thy knife; from a black man keep thy wife.

对肤色红的人可以讲心里话，同棕色的人可以分享面包，对肤色白的人要拔刀，对皮肤黑的人要当心你 的妻子。

Prejudice against colored people is felt nearly in every culture. It is believed that people with red skin are wise; those with brown skin are reliable; those with fair complexion are jealous; and those with dark complexion are lustful. Obviously, it is absurd to believe so, for no evidence comes up so far to prove that black people are lustful, white people are jealous and so on.

The division of labor in society should be treated as a natural result of social development, but, in the class society, superiority and inferiority have assumed the status of being two labels evaluating jobs of various kinds. Occupation discrimination has found plentiful expressions in English language. The author of this thesis just names a few here.

(47) A good servant should have the back of an ass, the tongue of a sheep, and the snout of a swine. 好仆人要有驴的背, 羊的舌, 猪的嘴。

It means that being a servant, one has to bear the weight of any goods tolerantly, keep his lips tight all the time, and eat the food of any kind.

(48) Nine tailors make a man. 九个裁缝才抵得上一个人。

Of course, this proverb is only a nasty gibe at the tailor. It means that tailors become thinner and weaker because of their strenuous work. As a result, nine tailors combined together are equal to a man of other profession. Without this proverb, Chinese readers will have no knowledge of tailor's being ill-treated in English-speaking countries.

2. Chinese Proverbs from Social Discrimination

The Chinese language, in all those above-mentioned aspects, is no exception, for China experienced a prolonged 
feudal society, which provided a hot bed for discrimination of all kinds to flourish. Women came first to be singled out as the target of prejudice at that time.

(49) 女人头发长见识短。

Women have long hair and short brains (or long hair and short wit).

(50) 女子无才便是德。

A virtuous woman has no talent.

Clearly, the feudalistic thinking deprived Chinese women of their right of being educated in the past. Now, it is quite ridiculous to say a woman of no talent has all virtues.

(51) 媳妇不打, 上房揭瓦。

A woman who is free from being beaten will surely show no restraint in her behavior.

This proverb clearly conveys the fact to English readers that women in the old China were put at the bottom of the family, and suffered a great deal in the hands of their husbands and husbands' parents.

(52) 男子走州过县，女人围着锅头转。

Men travel around the world, while women can only stay in the kitchen.

It was believed that women were born to be suitable for the housework because of their weak minds and bodies plus their personalities. Even though literal understanding of those proverbs cannot keep their styles, meanings of proverbs have been clearly presented. As Nida states in his book The Theory and Practice of Translation (1982) to

the effect that when translators are confronted with the dilemma of making a choice between meaning and style, meaning should take precedence over style.

(53) 好男不跟女斗。

A gentleman is above exchanging angry words with a woman.

The prejudice in this proverb is self-evident, for woman is regarded inferior to any man or gentleman, whoever is having words with any woman would be a condescending man.

Also, in Chinese feudal society, reading gains the top evaluation.

(54) 万般皆下品, 唯有读书高。

All occupations are base, only book learning is exalted.

(55) 两耳不闻窗外事, 一心只读圣贤书。

One should turn a deaf ear to all affairs outside and only fix his attention on book reading.

The significance of book learning can never be over-stated. But it would be wrong to regard book learning as the most respectable occupation under the sun, for the far- reaching significance of other occupations cannot be ignored or played down.

(56) 家有三斗粮，不做孩子王。 children.

As long as one has the food hardly enough to fill the stomach, one will never give any thought to be the king of

Profession of a kindergarten or a teacher elementary school was despised for a certain length of time by the whole Chinese society. One chooses to be a teacher only if any other job opportunities were closed to him and he was faced with starvation.

With space limited, the author just names a few proverbs that represent the relevant aspects. All in all, both English and Chinese languages have given birth to oceans of heavily culture-loaded proverbs in their respective course of development. They are fruits of the social development. They manifest "the way of life" of the two nations in various aspects. Without presentation of the origins of proverbs, we can hardly move a step forward in the mutual communication from cross-cultural perspective. Without a "cross-cultural perspective" principle, the vividness and expressiveness of Chinese or English proverbs will be sharply reduced to a flat and insipid level.

\section{CONCLUSION}

As more and more people of different culture background communicate with each other, we are more aware of the importance of the way cross-cultural communication is conducted. Proverbs, the cream of languages, mirror certain cultures and express ideas of human experiences in an explicit way. As the valuable treasure of different cultures, proverbs provide readers with plentiful information. Coming from various sources, proverbs present to readers a panorama of cultures to indicate how people are thinking, doing and communicating. Just because of their quintessential linguistic nature and their particular cultural traits, they play a lion in the way of cross-cultural communication, if improperly handled. Rhetorical devices employed by both Chinese and English proverbs, to a large extent, also manifest how people of different languages view the same or different things. However, owing to various reasons, peoples are always led into various understanding that the author of this dissertation has displayed in the previous chapter. As a result, the cross-cultural communication purpose will be hampered or misunderstanding between peoples will occur, which may inflict unexpected damage, or unpleasant result to communication.

Meaningful understanding of proverbs requires attention to the subtle aspects of cultural distinctions. As already discussed, human beings around the globe share, to a certain extent, some experiences, but the majority of their experiences are different, which are reflected in their respective cultures. It is these seemingly similar but actually 
different cultural traits that usually serve as hidden pitfalls for people. Cultural gap proves to be a chief obstacle to intercultural communication .In order to bridge it, people are required to conduct a careful comparative study of cultures implied in proverbs. At the same time, he should be engaged in improvement of languages, so as to increase his cultural awareness. While he is steeped in his native language and culture, he should also be at home in foreign language and culture. The competence of being bilingual and bicultural enables him to achieve an accurate understanding of his source text. Only by so doing can the purpose of proverb studying, which is to serve the cross-cultural communication, be achieved to the maximum degree.

\section{REFERENCES}

[1] Chaika, E. (1982). Language, the Social Mirror, Rowley, Massachusetts: Newbury House Publishers, Inc. [4]Smith, W.G. (1952) The Oxford Dictionary of English Proverbs. 20ded. Oxford: Claremont Press.

[2] Chen Wen bo. (1986). Understanding and translation of English idioms and proverbs. English -Chinese translation skills .Beijing: China foreign translation and publishing corporation.

[3] Du xue zeng. (1999). Comparison of Chinese and American cultural customs. Beijing: Foreign language teaching and research press.

[4] Fen qin hua. (1997). Practical translation course .Shanghai: Shanghai foreign language education press.

[5] Ge zhi hong, Meng li. (1999). Aphorism English900 sentences. Beijing: China book Publishing house.

[6] Guo jiang min. (1992). A Study of Chinese proverbs .Lanzhou: Gansu education press.

[7] Hu wen zhong. (1999). Introduction to intercultural communication. Beijing: Foreign language teaching and research press.

[8] Hu wen zhong. (2000). English idioms and Anglo-American culture Beijing.Foreign language teaching and research press.

[9] William H. and Judith S. (1975). The New Encyclopedia Britannica. The Third Edition edited London: The Macmillan Press Ltd.

[10] Zhen yi li. (1984). New English-Chinese dictionary The Second Edition Beijing . Beijing commercial press.

Rongmei Yu was born in Jiangxi province China in 1964. She received his Bachelor's degree in English Language and Literature from Jiangxi Normal University, China in 1989.

She is currently a professor in Nan Chang Normal University, Jiangxi, China. Her research interests include Intercultural Communication and English Teaching.

Prof. Yu is a member of Jiangxi Translation Association and the teacher of Nan Chang Normal University. 